\title{
Warming of one hand causes sustained increases in skin surface temperature and water content of the contralateral forearm
}

\author{
Ruriko Okada $^{1}$, Kanji Matsukawa ${ }^{2}$, Toshio Kobayashi ${ }^{3}$ and Yukiko Miyakoshi ${ }^{4}$ \\ ${ }^{1}$ 愛媛県立医療技術大学保健科学部看護学科，干791-2101 愛媛県伊予郡砥部町高尾田543 (Department of Nursing, Faculty of \\ Health Sciences, Ehime Prefectural University of Health Sciences, 543 Takooda, Tobe-cho, Iyo-gun, Ehime, 791-2101, Japan) \\ 2 広島大学大学院医歯薬保健学研究院生理機能情報科学研究室, 干734-8551 広島市南区霞 1-2-3 (Department of Integra- \\ tive Physiology, Graduate School of Biomedical and Health Sciences Hiroshima University, 1-2-3 Kasumi, Minami-ku, \\ Hiroshima 734-8551, Japan) \\ ${ }^{3}$ 広島大学大学院医歯薬保健学研究院健康開発科学研究室, 干734-8551 広島市南区霞 1-2-3 (Department of Health Develop- \\ ment, Graduate School of Biomedical and Health Sciences Hiroshima University, 1-2-3 Kasumi, Minami-ku, Hiroshima 734- \\ 8551, Japan) \\ ${ }^{4}$ 広島大学大学院医歯薬保健学研究院基礎看護開発学研究室, 7 734-8551 広島市南区霞 1-2-3 (Department of Fundamental \\ Nursing, Graduate School of Biomedical and Health Sciences Hiroshima University, 1-2-3 Kasumi, Minami-ku, Hiroshima \\ 734-8551, Japan)
}

Received: March 15, 2013 / Accepted: June 20, 2013

\begin{abstract}
This study aimed to develop a new method of increasing water content in the cutaneous stratum corneum under a dry skin condition. For this purpose, the experiments were performed using 10 healthy women (age: $20 \pm 5$ years, height: $158 \pm 4 \mathrm{~cm}$, weight: $50 \pm 6 \mathrm{~kg}$ ) in winter to ensure the dry condition. The subjects immersed the right hand into a $42^{\circ} \mathrm{C}$ bath for $10 \mathrm{~min}$. Skin surface temperature and water content in the stratum corneum of the left forearm were simultaneously measured during and for $1 \mathrm{~h}$ after the hand warming. The skin surface temperature began to increase $(\mathrm{P}<0.05) 15 \mathrm{~min}$ after the hand warming and thereafter remained increased for $1 \mathrm{~h}$. Similarly, the water content in the stratum corneum began to increase immediately after the hand warming and remained increased throughout the experiment. The present results suggest that warming of one hand is effective in enhancing skin moisture in the other forearm and thereby maintaining barrier function of the skin.
\end{abstract}

Jpn J Phys Fitness Sports Med, 62(4): 315-321 (2013)

Keywords : hand bath, water content, skin surface temperature, stratum corneum

\section{緒言}

冬季における大気の乾燥やエアコン使用による低湿等 で，ドライスキンという病態が生じる。これは，皮膚の 角層に含まれる水分量（以下，角層水分量）が減少した 状態を指す。この角層水分量は, 皮脂量や角質細胞間脂 質などの影響を受ける保湿能と相対湿度に依存するた め, 皮脂が少ない小児や高齢者, 角質細胞間脂質が減少 するアトピー性皮膚炎患者は, ドライスキンに傾きやす (い)。ドライスキンは皮虐バリア機能を低下させるが, 角層のバリア機能と水分保持機能の間には相関性が認め られる。バリア機能の低下によって，水分の保持は困難 となり, 乾燥して角層が剥がれ落ちて鱗屑を形成する。 さらに乾燥で亀裂が生じれば，ますます環境からの刺激
を受けバリア機能が低下し ${ }^{21}$ ，アレルギー惹起，感染症 合併, 痒みの誘発など多彩な病態を呈するようになる3).

低下した皮膚バリア機能を回復させる目的で，水分蒸 散を抑制し，角層水分量を維持するための外用保湿剂塗 布に関する研究が盛んに行われてきた ${ }^{4-9)}$ ，角層水分に 関する研究はこのほか, 浴用剤の影響10,11)，季節や環境 による角層水分量の変動掞よび身体部位間の比較 ${ }^{12-16)}$, 全身浴やサウナに伴う角層水分量の変化 ${ }^{17-20)}$ に関する報 告があるが，手浴などの部分温熱刺激による身体内部か らの角層水分への影響には着目されてこなかった，我々 はこれまでに，10分間の片側の手浴で，対側前腕の角層 水分量が増加することを報告した ${ }^{21-24)}$. この所見から, 片側手浴の温熱刺激が, 皮膚交感神経活動を減少させ, 手浴側のみならず対側前腕の皮膚血管拡張・皮膚血流量 
の増加を促進し, 増加した皮膚血流量が角層に水分を与 えて保湿するという体内加皮膚表層への水分供給义カ ニズムを着想した25)。 そこで, 本研究では, 角層水分量 が減少した皮膚でみられる皮膚バリア機能低下を予防す る方法を開発するため, 低湿環境にある冬季（12月～1 月）に実施した片側手浴による温熱刺激が対側前腕部の 角層水分量に及ぼす影響を調べた。

\section{方 法}

被験者 皮膚障害のない健康な女性10名 (年齢 $20 \pm 5$ 歳, 身長 $158 \pm 4 \mathrm{~cm}$, 体重 $50 \pm 6 \mathrm{~kg}$ ）に対し，2010.12月～ 2011.1月に, 室内温度 $21.3 \pm 1.4^{\circ} \mathrm{C}$, 室内湿度 $50.6 \pm 4.2 \%$, 室外温度 $5.5 \pm 1.6^{\circ} \mathrm{C}$, 室外湿度 $58.8 \pm 8.3 \%$ という環境で 実験を行った。実験前日の睡眠時間は 7 時間以上を確保 し，測定開始時には食後 2 時間を経過していること，衣 服は下着の上にトレーナー 1 枚程度の軽装であること を条件とした，実験開始前には血圧・脈拍・体温測定に より健康状態を確認した。実験中は熱感や冷感等の不快 の有無に留意し, 下肢冷感を訴えた被験者 2 名について は,ひざ掛けを用いた，なお，各被験者には，研究の目 的・方法㧍よび倫理的配慮に関して文書と口頭で説明し, 文書で同意を得た。本研究は, 愛媛県立医療技術大学研 究倫理委員会の承認を得て行った（承認番号：10-012）.

実験手順および測定方法 筆者らの先行研究では, 12月21,22) と 4〜6 月 ${ }^{23-25)}$ の 2 つの季節で, 手浴終了後30分までの 測定を行ったが，今回は，冬季（12月～1月）に拈ける 手浴後60分までの温熱刺激の効果を調べた。片側手浴と して, 恒温水槽（サーモペット-NTT130; 東京理科器械, Japan）の $42 \pm 0.05^{\circ} \mathrm{C}$ の湯に, 椅坐位にて, 片側手部の 橈骨茥状突起部までを10分間浸漬して温熱刺激を加える 方法を用いた（以下，手浴あり). 手浴後の片側手部は タオルで水分を拭き取った後は被覆せず，測定を行う対 側前腕部・手部も被覆しなかった，対照として，同一被 験者に，手浴なしで椅座位を10分間保持するという条件
で, 同様の測定を実施した(以下, 対照)。手浴ありのデー 夕測定は，手浴開始時と手浴中10分間，ならびに手浴終 了後60分経過時までの計70分間にわたり 5 分毎に行っ た。対照のデー夕測定もこれに準じた，手浴ありと対照 の測定は, 冬季の寒冷刺激によって変化しやすい被験者 の体調や皮膚の状態を考虑し, 条件を統一する意味で同 日に実施した。実施順は，30分間の環境馴化後，最初に 対照データを測定し，15分間の休息後に各項目が対照の 測定開始時の值と差がないことを確認した上で手浴あり を実施した。これは，予備実験で手浴ありを先行した場 合には, 皮虐への影響が強く残り, 続く対照デー夕の測 定に信頼性を欠いたためである。

測定項目は，角層水分量，皮膚表面温，皮下媣部温な らびに血圧であった，角層水分量は，皮表水分量測定機 (Corneometer-CM825; COURAGE-KHAZAKA, Germany）を用いて, 対側前腕内側の肘窩から長軸方向の $2 \mathrm{~cm} \times 8 \mathrm{~cm}$ 範囲内を 5 箇所測定し, その平均值を一経 過時点のデータとした。皮膚表面温は，熱流補償式体温 計（コアテンプCTM205;TERUMO, Japan）を用いて, 対側前腕内側肘窩と手関節を結ぶ中間地点に表面温測定 用プローブを装着して測定した。また，核心温に近似し たデー夕を得る目的で, 大動脈弓の直上に位置する左前 胸部の第一肋間胸骨左縁に, 同じ体温計の泾部温測定用 プローブを装着し, 胸部皮下深部温を測定した。血圧は, ベッドサイドモニター（ライフスコープ P-BSM4101； 日本光電, Japan）を用い, 専用カフを手浴側の上腕に装 着して測定した（Fig. 1).

データ分析ならびに検定 70分間の経時的データをMean $\pm S E$ で示した，分析は，手浴開始直前の值（0 時点）を 基準值とし, 予め各測定項目に扔ける手浴ありと刘照の 間で基準值に差がないことを対応のある $\mathrm{t}$ 検定で確認し た，その後，基準值と経時的デー夕をBonferroniの方法 で多重比較した，さらに，手浴ありと対照の対応する経 過時点の差を, 対応のある $\mathrm{t}$ 検定で確かめた。 な挹, 角

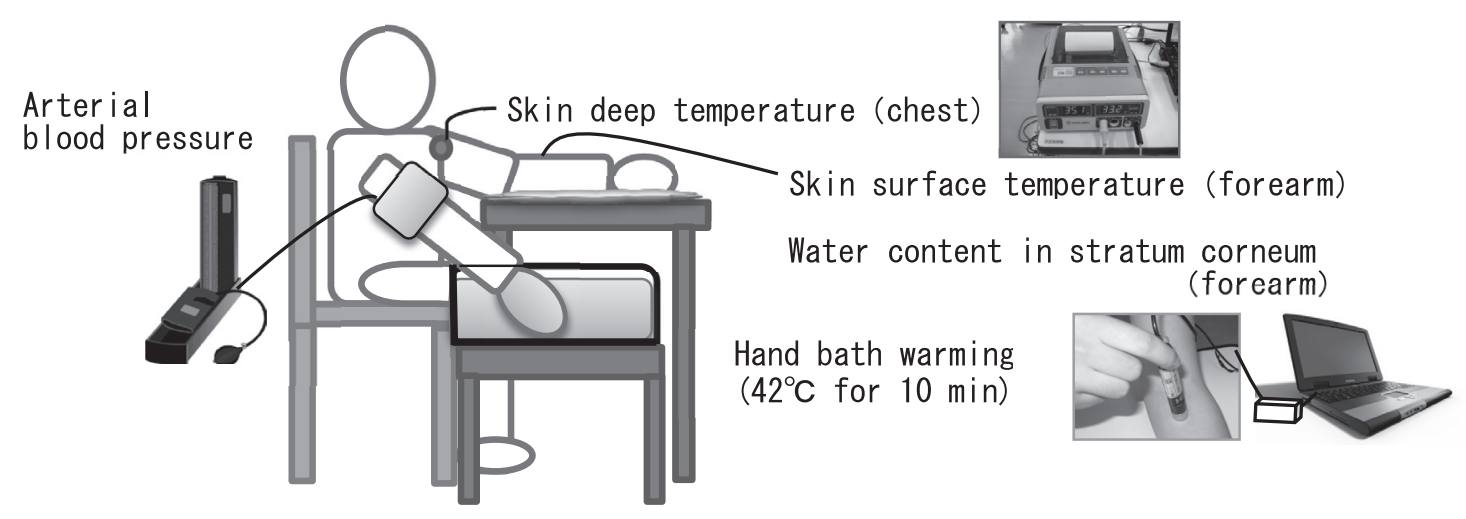

Fig. 1 An experimental setup 
層水分量については，実測值とともに，基準值を100\% とした変化率も算出し, Bonferroniの方法および対応の ある $\mathrm{t}$ 検定で比較した. 有意水準はいずれも $\mathrm{P}<0.05$ とし, 統計ソフトはSPSS Statistics Ver.19を使用した。

\section{結 果}

胸部皮下深部温と血圧 胸部皮下深部温は，手浴ありと 対照の各基準值と経時的データ，および両者間の対応す る経過時点のいずれにおいても有意な差を認めなかった (Fig. 2). 収縮期血圧は，各基準值と経時的データの間 には差を認めなかった. 手浴ありと対照の比較において, 手浴開始 5 分経過時点のみで,手浴ありが $103 \pm 2.6 \mathrm{mmHg}$
となり有意に高值であったが（P<0.05， Fig. 3)，それ以 降には差がなかった。拡張期血圧に関しては，いずれの 比較においても有意な差を認めなかった（Fig. 3).

皮膚表面温と角層水分量 皮膚表面温は, 対照の場合, 基準值と比べ $2 \%$ 程度の低下傾向を示した。手浴ありで は，手浴終了後10分から有意に上昇し始め $(\mathrm{P}<0.05)$, 手浴終了後 15 分で $2.3 \%$ 上昇し $(\mathrm{P}<0.01)$, 以後60分経過 時まで高值を維持した（P<0.01，Fig. 4)，また，手浴あ りと対照の比較では，手浴ありの方が手浴終了後15分か ら60分経過時まで有意に高值であった（P<0.05, Fig. 4). 角層水分量の実測值は，対照においては有意な変化

$\left({ }^{\circ} \mathrm{C}\right)$

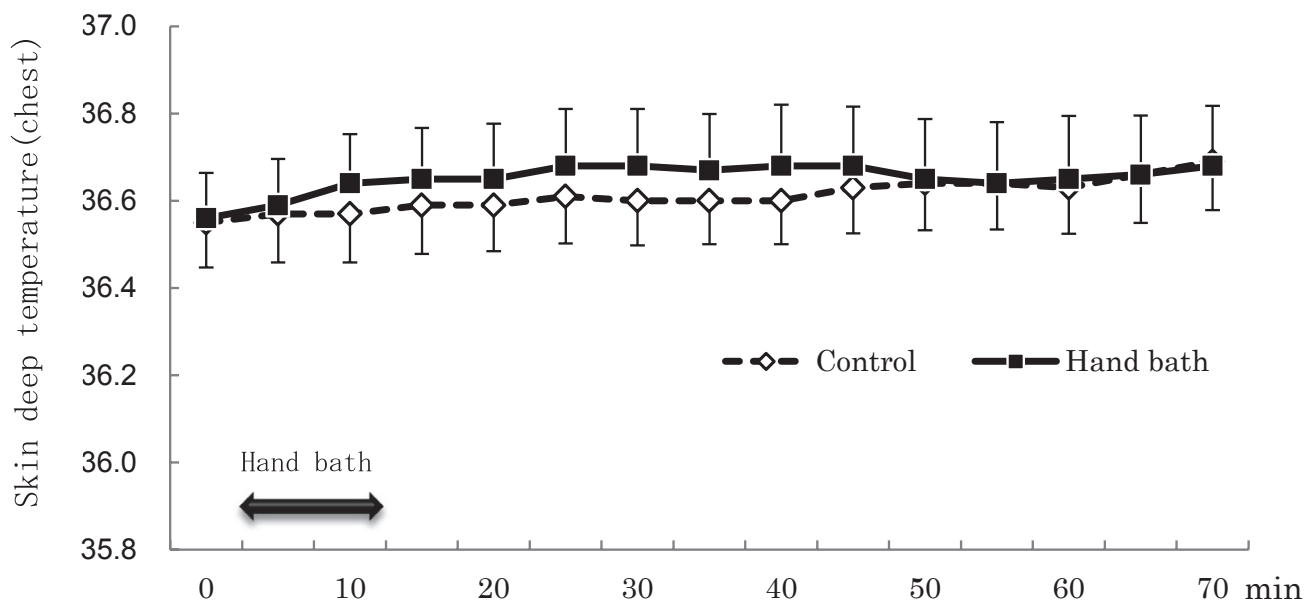

Fig. 2 Changes in skin deep temperature in the chest

Skin deep temperature was measured in the chest with and without hand bath warming for 10 min. Control, without hand bath warming.

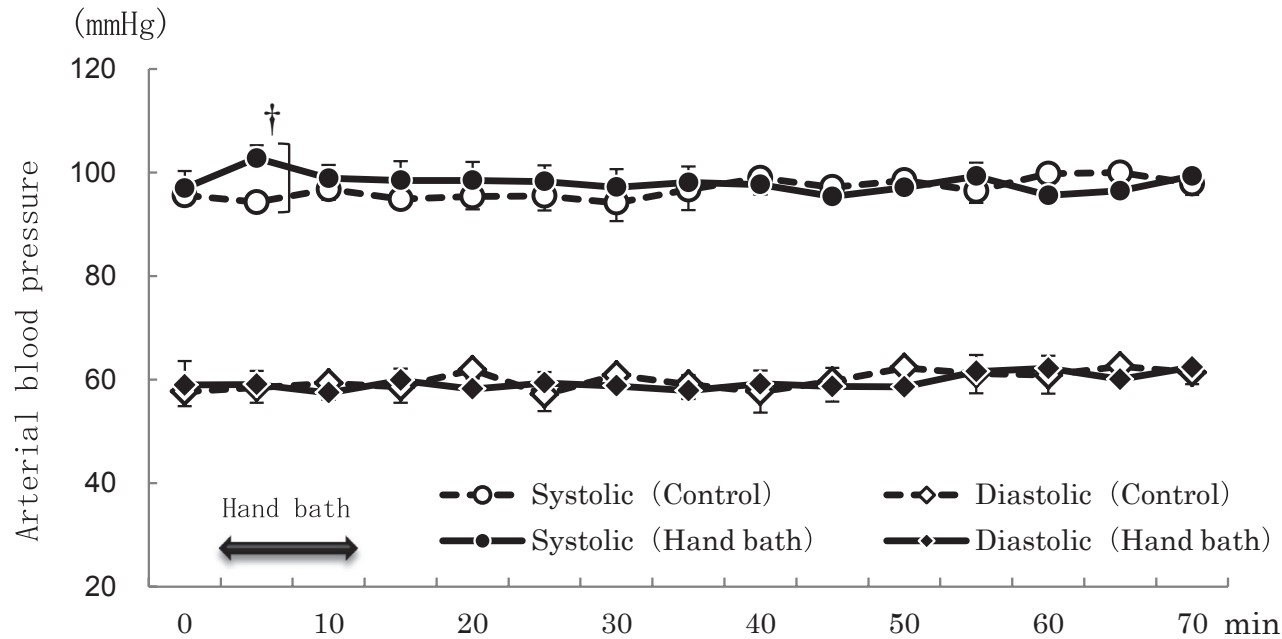

Fig. 3 Changes in arterial blood pressure

The differences in systolic and diastolic blood pressure between control and hand bath were compared by a paired t-test. $\uparrow, \mathrm{P}<0.05$. 


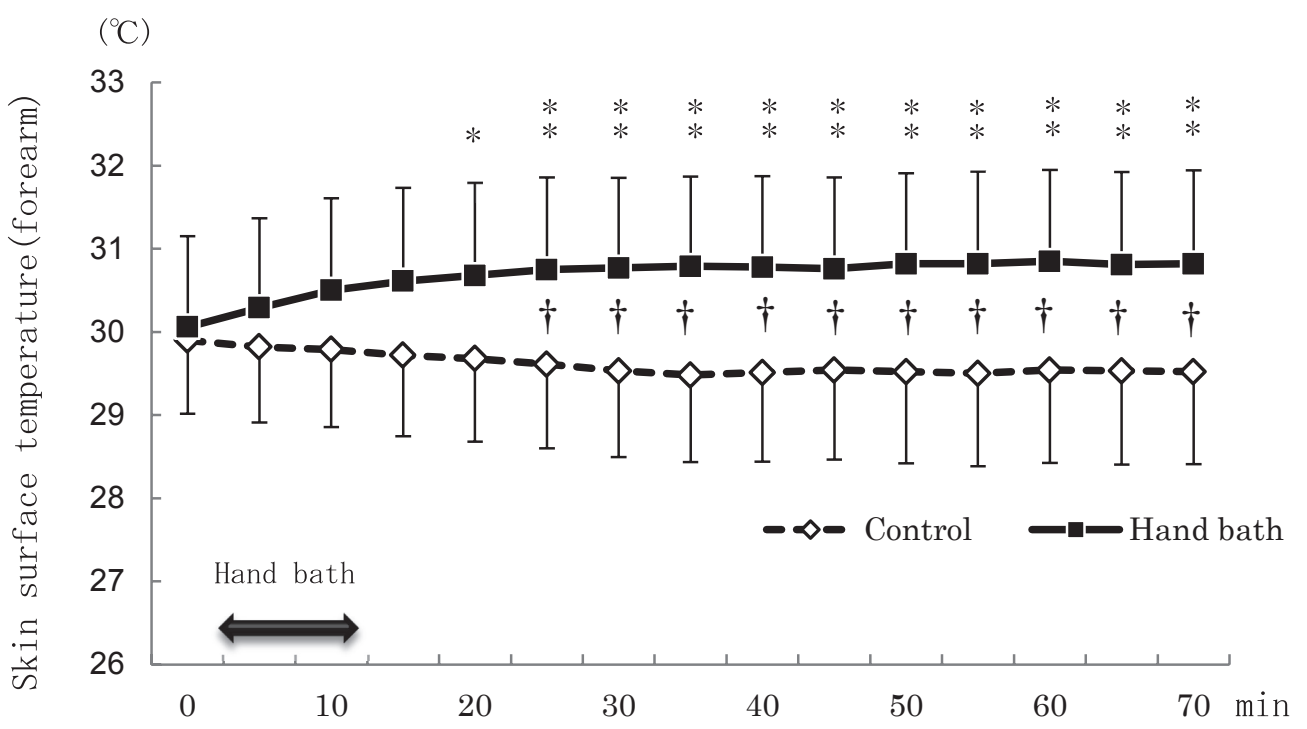

Fig. 4 Changes in skin surface temperature in the forearm ${ }^{*} \mathrm{P}<0.05$, * $\mathrm{P}<0.01$ : Significant difference from the prewarming value. $\uparrow \mathrm{P}<0.05$ : Significant difference between control and hand bath.

を認めなかった（Fig. 5A)，手浴ありでは，基準值と 比へ，角層水分量は手浴開始後10分で有意に増加した $(\mathrm{P}<0.001)$. 以後, 手浴終了後10分・15分を除いて手浴 終了後60分経過時まで高值を維持した $(\mathrm{P}<0.05$, Fig. $5 \mathrm{~A})$. 手浴ありと対照間の比較では, 手浴終了後15分 . 25分・30分で手浴ありが対照よりも有意に高值であっ た $(\mathrm{P}<0.05)$. 角層水分量の変化率に打いても, 対照は, 基準值と比べて有意な差を認めなかった（Fig. 5B）。一 方, 手浴ありでは, 角層水分量の変化率は手浴開始後 10 分で約 $5 \%$ の増加を認め $(\mathrm{P}<0.001)$, 手浴終了後10分. 15分を除いて手浴終了後60分経過時まで高值を維持した $(\mathrm{P}<0.05$, Fig. $5 \mathrm{~B})$ ．手浴ありと対照の比較では，手浴終 了後 10 分· 35 分・40分を除き, 手浴開始後10分から手浴 終了後60分経過時まで，手浴ありが対照よりも有意に高 值であった（P<0.05, Fig. 5B).

\section{考察}

片側の温熱刺激が深部体温や循環動態に及ぼす影響

胸部皮下深部温は, 片側手浴の温熱刺激では変化しな かった。ヒトの核心温は一定の狭い温度域に維持されて いるが，病的状態や暑熱負荷が強すぎる場合には上昇を 示すことがある26). しかし, 本研究の $42^{\circ} \mathrm{C}$ の温湯を用い た10分間の片側手浴の温熱刺激は，核心温に影響を及ぼ す程の温熱負荷ではなかったために, 胸部皮下深部温に も変化がなかったものと推察される.

血圧の変化については，手浴ありの収縮期血圧が，手 浴開始 5 分のみで対照時に比べて有意な上昇を示した。 これは, 温熱刺激に伴い交感神経活動が増加し一時的に 血管抵抗が増大したことによるものと推察される，湯温

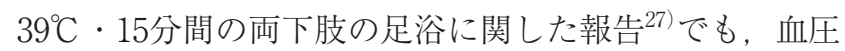
值の変化は確認されなかったため, 本研究の片側手浴が 及ぼす循環系への負荷は軽微なものといえる.

以上のことから, $42^{\circ} \mathrm{C} \cdot 10$ 分間の片側手浴による温熱 刺激は, 核心温や全身循環動態の変化をもたらす程の負 荷ではないことが確認できた。

\section{片側の温熱刺激が対側前腕の皮膚表面温に及ぼす影響}

対側前腕の皮虐血管の拡張を示す 1 つの指標である皮 膚表面温は, 片側の手浴により手浴終了後60分経過時ま で上昇することが確認された。これに関連して，両前 腕への10分間の温罨法（開始時湿布表面温 $43 \sim 44^{\circ} \mathrm{C}$ ) に よる左膝蓋骨上部の皮膚温の上昇 ${ }^{28)}$ ，および両前腕を 40 $\sim 41^{\circ} \mathrm{C}$ の湯に10分間浸漬した場合に㧍ける下腿部皮膚温 の上昇 ${ }^{29)}$ な゙，温熱刺激部位から遠隔の皮膚表面温の持 続的上昇の報告がある。これらの研究は前腕への $40^{\circ} \mathrm{C}$ 以 上の温熱刺激を10分間負荷した点では本研究と共通する が, 手部〜前腕への広範囲かつ両側性の刺激という点で, 本研究とは異なる。類似した研究として片側の手部のみ を $39^{\circ} \mathrm{C}$ の湯で手浴した場合に, 対側の拇指球部の皮膚表 面温が手浴後30分経過時点でも有意な上昇を認めた報 告 ${ }^{30)} も$ あが, 手浴後の 60 分経過時点までは調べられ ていない，本研究は，片側の手部に限局した小範囲の温 熱刺激によって, 非温熱刺激側の上肢前腕の皮膚表面温 を手浴後60分にわたり上昇させるという新しい現象を 明らかにしたものと言える。

最初に, 胸部皮下深部温の上昇を伴わずに皮膚表面温 が上昇したメカニズムについて考察する。この皮膚温上 昇は, 片側手部への部分温熱刺激であるため, 全身浴な 
A

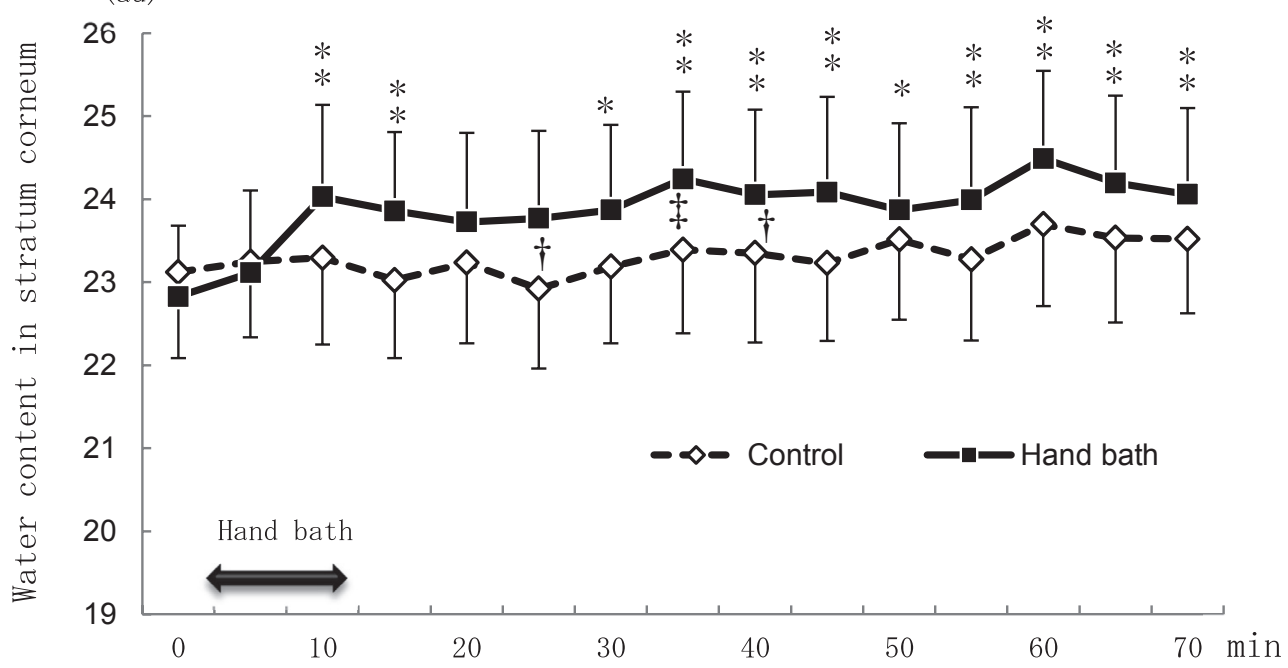

B $(\%)$

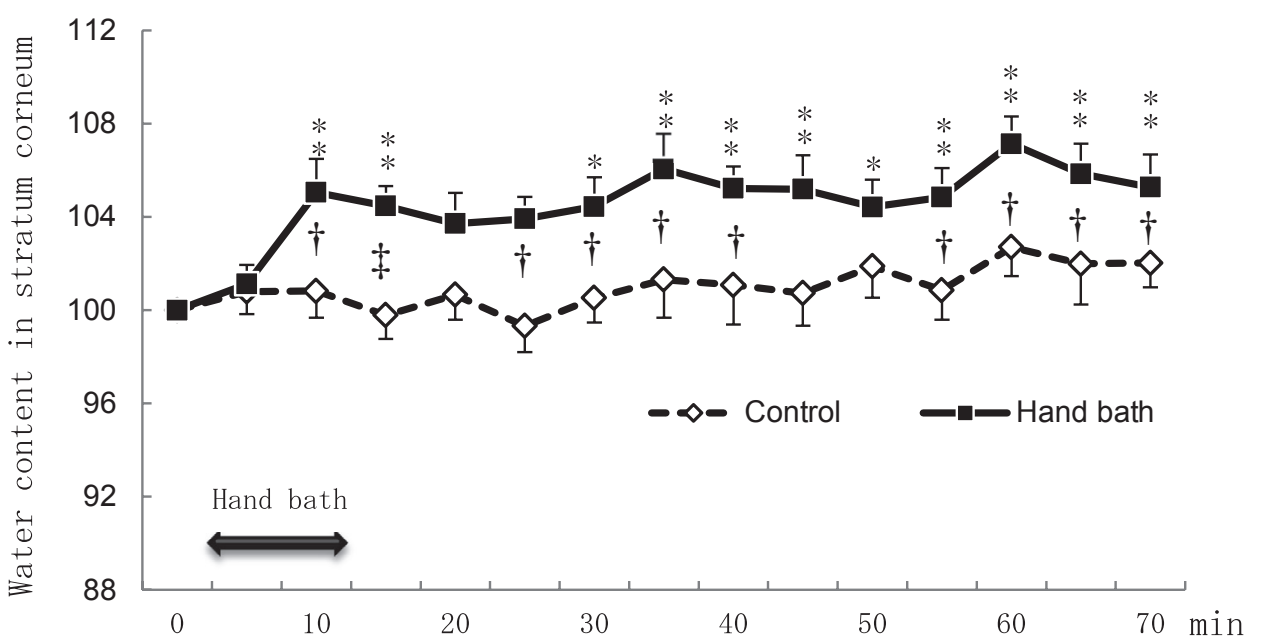

Fig. 5 Changes in water content of the stratum corneum

A, absolute changes in water content. B, percent changes in water content. au, arbitrary unit.

${ }^{*} \mathrm{P}<0.05, \quad{ }^{*} \mathrm{P}<0.01$ : Significant difference from the prewarming value.

$\dagger \mathrm{P}<0.05$, $\$ \mathrm{P}<0.01$ : Significant difference between control and hand bath.

どの多大な温熱負荷での熱伝導によるものではなく, 反 射性の反応としてとらえることができる。つまり，この 片側手部に加わった温熱刺激を皮膚温度受容器が感知 し，体温調節中枢に伝達された結果，血管収縮交感神経 活動の抑制を介する皮虚血流量増加によって, 皮虚表面 温が上昇したものと考えられる ${ }^{31)}$ 。つまり, 皮膚温度受 容器により環境温を検出して, 体温調節中枢に情報を伝 え, 体温が変化することを予め見越して効果器が作動す る予測制御（フィードフォワード制御）の関与が考えら れる。 また皮膚表面温受容器は温度変化に対して強い反 応を示し，環境温度の絶対值よりも，むしろその変化を 検出する特徵がある ${ }^{31)}$. 12 月〜 1 月に実施した本研究の $42^{\circ} \mathrm{C}$ という比較的高めの温湯による手浴は, 寒冷刺激に
さらされている冬季の手部皮膚の温受容器を効果的に刺 激し，温度変化を強く感じさせて，効果器としての皮膚 血管の拡張を促すことに大きく関与したとも考えられ る。ささには，片側の下肢などへの部分的な温熱刺激の 影響は局所にとどまらず，他方の上下肢や遠隔部に反射 的に作用するとの報告から ${ }^{32,33)}$ ，片側手浴により対側手 部の動静脈吻合が開大し，対側前腕の表在静脈の血流量 が増加した結果，皮虐表面温が上昇した可能性も考えら れた

次に，片側手浴終了後 1 時間にわたり，皮膚表面温度 が高值を維持したメカニズムについて考察する．40〜 $42^{\circ} \mathrm{C}$ の 10 分間の密閉式足浴抒よび $43 \sim 44^{\circ} \mathrm{C}$ の前腕部温 罨法で, 指腹部の皮膚血流波形の周波数解析から自発性 
周期的動摇の抽出を行った報告28)では,加温後60分まで, 周期的動摇の徐波化が認められ，血管運動を制御する交 感神経活動が減少した可能性を指摘している。また, 手 浴・足浴を用いた研究 $30,35-37)$ においても，脈拍数や心拍 変動による自律神経活動や主観的快適感覚などが測定さ れて副交感神経活動の賦活化やリラクゼーション効果が 起こることが報告されていることから, 本研究において も，手浴終了後60分間にわたり交感神経活動の低下が 持続することで, 皮虐血管の拡張が持続した可能性があ る.ささらに, 筆者らの予備研究で (未発表), 前腕部皮下 深部温も皮膚表面温と同様の上昇を認め, 皮下 $1 \mathrm{~cm}$ に おける前腕部の深部血流も増加している可能性を示唆し た。したがって,この前腕部皮下深部温の上昇, つまり 前腕部皮下の媣部血流量の増加が皮膚表面温の低下を防 ぎ高値を維持することに寄与した可能性が考えられる。 さらに, 筆者らが10１1月の秋季に行った研究（未発表） では, 皮膚表面温の有意な上昇は手浴終了後40分経過時 点でとどまっていたため, 季節による身体反応の違いも 大きいのではないかと推察される。

\section{片側の温熱刺激が対側前腕の角層水分量に及ぼす影響}

角層水分量の変化に関しても, 片側手浴の温熱刺激は, 手浴開始後 10 分で角層水分量を増加させ，手浴終了後 60 分経過時点においても高值を維持することが明らかと なった。これに関連して，湯に直接浸漬した皮膚に挍け る角層水分量を観察した研究では, 入浴後, 角層水分量 は一時的に増加するが，直ちに入浴前の状態に戻るか ${ }^{18)}$ あるいは減少する17)ことが示されている。これらは，身 体外部からの水分の吸水による角層水分量の変化を示し たものであり, 本研究とは着目している水分供給源が異 なっている, 本研究のように, 身体外部からの吸水によ らない角層水分量の増加現象を明らかにした報告はこれ までに見当たらない。

温熱刺激による角層水分量の増加に関するメカニズム について考察する。身体外部からの吸水によらない角層 水分量の増加には, 体温調節機構の発動に伴う対側前腕 の皮膚血管の拡張が関与している可能性が考えられる. 片側手浴の温熱刺激により皮膚交感神経活動が減少する ことで皮膚血管が拡張し ${ }^{31)}$ ，加えて手部の動静脈吻合の 開大による対側前腕の皮膚血流量の増加により ${ }^{32-34)}$, 対 側前腕の皮膚細動脈の拡張, 毛細血管への血流量増加, 毛細血管からの水分滤過量が増加し，角質細胞間拉よび 汗腺への水分供給が行われたものと解釈できる。つまり, 増加した皮膚血流量が角層水分量を増加させるという身 体内部からの皮膚保湿効果を検証したと考えられる。

角層水分量の増加が手浴終了後 1 時間にわたって維持 されたメカニズムについては, 皮虐表面温の上昇のメカ ニズムの考察で述べたと㧍り, 皮膚交感神経活動の減少
による皮膚血管の拡張が長時間持続したことに起因する 可能性がある。このような温熱刺激による角層水分量へ の影響について，サウナによる高温曝露時の変化に関す る報告 ${ }^{20)}$ がある。そこで示されている温熱刺激による角 層水分量は, 水分蒸散量の経時的変化と同様にサウナ後 5 分で最大となったが，15分以降には初期の值に戻って いた。これは，サウナという高温暴露により皮虐血管は 最大限に拡張して皮膚表層へ水分が移動し，さらに発汗 による皮膚表層への水分浸潤が生じて角層水分量は一時 的にプラスに転じたが，その後の多量の発汗による水分 蒸散量の増加によって皮膚表層の水分培失を招くこと で，早期の角層水分量の減少をもたらしたものと解釈し た。これに関連して，筆者らは，冬季に， $37^{\circ} \mathrm{C} \cdot 40^{\circ} \mathrm{C}$. $43^{\circ} \mathrm{C}$ の 3 種類の温湯による 10 分間の片側手浴に対する 皮膚表面温への影響を手浴終了後20分まで測定した ${ }^{21)}$. 3 種類の温湯ともに皮膚表面温は開始 8 分頃より同様に 上昇したが， $37^{\circ} \mathrm{C} \cdot 40^{\circ} \mathrm{C}$ の場合には角層水分量の増加を

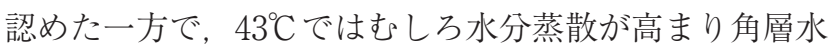
分量は手浴開始直後より減少に転じた. 以上のことから, サウナゃ $43^{\circ} \mathrm{C}$ 以上の温湯による高温の温熱刺激は, 皮 膚血管拡張による皮膚表層への水分供給量よりも皮膚表 面からの蒸散による水分喪失量が上回ることで，結果的 に角層水分量の減少をもたらすことが考えられた，つま り，本研究に扔ける $42^{\circ} \mathrm{C} \cdot 10$ 分間の片側手浴は，皮膚表 層からの蒸散・発汗が少なく水分㳖失量を一定レベル以 内に抑えることで，皮膚角層に供給された水分量が貯蔵 され維持されたのではないかと解釈された。

以上のことから, $42^{\circ} \mathrm{C} \cdot 10$ 分間の片側手浴は，体温調 節機構の発動により, 対側前腕の皮虐表面温の上昇, つ まり皮膚血管の拡張・皮膚血流量の増加を生じさせ，角 質細胞間および汗腺への水分供給を行うことにより角層 水分量増加をもたらしたものと解採された。さらに，多 量の水分蒸散に至らず保湿成分を維持した状態で行える 温熱刺激法であることも, 角層水分量維持に貢献するこ とが示唆された。

な押，本研究は，冬季に打ける皮膚保湿能の高い被験 者の前腕皮膚に限局した成果である。今後は，冬季以外 の季節に扔ける片側手浴の皮膚への影響や，皮虐乾燥が 著しい対象者層に打ける全身の皮膚角層水分への影響を 測定していきたい.

\section{謝 辞}

本研究を行うにあたり, 研究の趣旨をご理解いただき, 快く協力してくださった全被験者の皆様に，深く感謝いた します。

\section{引用文献}

1）宮地良樹, 角層の生理学, 図解皮膚科学テキス卜, 石川 治・宮地良樹, 中外医学社, 東京都, 37-40, 2003. 
2）田上八郎：アトピー性皮膚炎と皮膚のバリア機能, ア レルギー, 54: 445-450, 2005.

3）宮地良樹, 長沼雅子：化粧品・外用薬研究者のための 皮膚科学, 文光堂, 東京都, 6-124, 2005.

4）須貝哲郎：皮膚の保湿-序論, 皮膚, 27: 272-275, 1985.

5）李 梅花, 上田秀雄, 杉林堅次, 森本雍憲: 角質保湿剂七 アルロン酸ナトリウムの皮膚浸透に及ぼす超音波照射 の影響, Drug delivery system 12: 415-419, 1997.

6）渡辺 靖, 鏑木公夫, 戸沢孝之：乾燥性の皮膚症状に対す る薬用あれ肌ローション (XDV-1) の使用成績, 西日 皮膚, 60: 702-706, 1998.

7）古賀哲也, 古江増隆, 西江温子: 精製ツバキ油配合クリー ムの安全性および有用性の検討, 西日皮膚, 65: 616-619, 2003.

8）新井香奈子, 石垣和子：高齢者のドライスキンに対す る保湿クリーム塗布効果の検討, 日本生理人類学会, 10 : 76-77, 2005.

9）川島 眞, 林 伸和, 乃木田俊辰, 柳澤恭子, 水野惇子：ア トピー性皮膚炎の寛解維持における保湿剤の有用性の 検討, 日本皮膚科学会雑誌, 117: 1139-1145, 2007.

10）渡邊 智, 永井克介, 川崎義巳: 浴用剂の皮膚への効果, FRAGRANCE JOURNAL 2: 25-29, 1993.

11）渡邊 智, 永井克介, 川崎義巳, 阿岸祐幸：アルカリ塩類 浴による皮膚柔軟性, 皮膚粘弾性及び皮膚角質水分量に 関する研究, 日温気物医誌, 57: 272-277, 1994.

12）吉国好道, 田上八郎, 白浜茂穂, 佐野勉, 井上邦雄, 山田 瑞穂：身体各部位における皮表角層水分量の季節的変 化とそれに関与する因子について, 日皮会誌, 93: 491495, 1983.

13）徳留康子, 田上八郎：皮膚の老化と角層の水分保持能, 日皮会誌, 96: 493-496, 1986.

14) Denda M, Sato J, Tsuchiya T, Peter M, Kenneth R. Low humidity stimulates epidermal DNA synthesis and amplifies the hyperproliferative response to barrier disruption: implication for seasonal exacerbations of inflammatory dermatoses. J Invest Dermatol 111: 873-878, 1998.

15）松本雅之, 林照次, 新井清一：角層剥離パターンによる 角層評価（第 2 報）-季節変化と年代差について一, 香 粧会誌, 24: 1-6, 2000 .

16) Marrakchi S, Maibach HI. Biophysical parameters of skin: map of human face, regional, and age-related differences. Contact Dermatitis 57: 28-34, 2007.

17）橋本みづほ，佐伯由香：皮膚の水分量・油分量・PHな らびに清浄度からみた清拭の効果, 日本看護技術学会 誌, 2: 61-68, 2003.

18）佐伯由香, 橋本みづほ, 深井喜代子：湯使用後の手背部 皮膚表面の変化ならびに保湿ケアの検討, 看護人間工 学研究誌, 7: 23-28, 2006.

19）中野雅子：高齢者の入浴後の皮膚油分・水分の回復プ ロセスと皮膚乾燥傾向に関する研究, 京都市立看護短期 大学紀要, 34: 75-81, 2009.

20) Kowatzki D, Macholdt C, Krull K, Shumidt D, Deufel T, Elsner P, Fluhr J.W. Effect of regular sauna on epidermal barrier function and stratum corneum waterholding capacity in vivo in humans: a controlled study.
Dermatology 217: 173-180, 2008

21）岡田ルリ子, 徳永なみじ, 昆 和典：温浴がもたらす皮膚 生理機能への影響-角層水分量・水分蒸散量の見地か ら一, 愛媛県立医療技術大学紀要, 3: 45-49, 2006.

22）岡田ルリ子, 徳永なみじ, 昆 和典：温浴による皮下血流 量増加がもたらす角層水分量への影響, 日本看護学教 育学会, 第16回学術集会講演集: 155, 2006.

23）岡田ルリ子, 徳永なみじ, 相原ひろみ, 和田由香里, 昆 和典：手浴の温熱刺激がもたらす皮膚保湿効果-第 1 報-, 日本看護技術学会, 第 7 回学術集会講演抄録集: 65 , 2008.

24）徳永なみじ, 岡田ルリ子, 相原ひろみ, 和田由香里, 昆 和典：手浴の温熱刺激がもたらす皮膚保湿効果-第 2 報-, 日本看護技術学会, 第 7 回学術集会講演抄録集: 66 , 2008.

25）岡田ルリ子, 徳永なみじ, 相原ひろみ, 宮腰由紀子：部 分温浴がもたらす皮膚保湿効果, 日本看護技術学会, 9: 45-49, 2010.

26）入來正躬, 体温の調節と調節中枢, 体温のバイオロジー 一体温はなぜ $37^{\circ} \mathrm{C}$ なのー, 山蔭道明, メデイカル・サ イエンス・インターナショナル, 東京, 2-12, 2005.

27）竹本由香里, 高橋方子, 佐々木裕子, 丸山良子, 山本真千 子：座位による足浴がもたらす生理学的効果について 一自律神経活動と循環動態からの評価, 宮城大学看護学 部紀要 10: 37-45, 2007.

28）吉村美奈子, 野村志保子, 山田信一, 森本紀巳子, 飯野矢 住代, 加悦美恵 : 前腕部温罨法と密閉式足浴法が皮膚温, 皮膚血流量, 皮膚血流脈波形および主観的反応に及ぼす 影響, 日本生理人類学会誌, 14: 81-90, 2009.

29）安冨香苗, 工藤せい子, 石岡 薰, 會津桂子, 安杖優子, 工 藤うみ：手浴が上下肢皮膚温・深部温と心理面に及ぼ す影響, 看護技術, 55: 92-98, 2009.

30）岡田淳子, 深井喜代子：手浴が皮膚表面温, 温度感覚 および快適感に及ぼす影響, 川崎医療福祉学会誌, 13: 317-323, 2003.

31）彼末一之, 体温とその調節, 標準生理学 (第 7 版), 小澤 瀞司・福田康一郎, 医学書院, 東京都, 867-879, 2009.

32) P.P.A.Chanmugan, Eric Viel, 中村龍一, 益子宣雄, 熱の 物理学, 物理療法のすべて, 萩島秀男, 医歯薬出版, 東京 都, 31-56, 1993.

33）松澤 正, 目黒 力, 田子利法, 野田隆基 : ホットパック療 法における治療時間の検討, 群馬パース大学紀要, 4: 7-13, 1986.

34）平田耕造, AVA血流量と熱放散システム, 体温-運動時 の体温調節システムとそれを修飾する要因-, 平田耕 造・井上芳光・近藤徳彦, NAP, 東京都, 89-98, 2002.

35）金子健太郎, 熊谷英樹, 尾形 優, 竹本由香里, 山本真千 子：足浴が生体に及ぼす生理学的効果--循環動態・自 律神経活動による評価, 日本看護技術学会誌, 8: 35-41, 2009.

36）新田紀枝, 阿曽洋子, 川端京子：足浴, 足部マッサージ, 足浴後マッサージによるリラクゼーション反応の比較, 日本看護科学会誌, 22: 55-63, 2002.

37）工藤うみ, 工藤せい子, 冨澤登志子：足浴における新井・ 簡易マッサージの有効性, 日本看護研究学会雑誌, 29 : 89-95, 2006. 